\title{
Extraction and Chemical Compounds Identification of Red Rice Bran Oil Using Gas Chromatography - Mass Spectrometry (GC-MS) Method
}

\author{
Hoo Sheren Oktavia Hartono ${ }^{1, *)}$, Hartati Soetjipto ${ }^{1, * *}$, dan A. Ign. Kristijanto ${ }^{1)}$ \\ 1) Jurusan Kimia, Fakultas Sains dan Matematika, Universitas Kristen Satya Wacana \\ J1. Diponegoro no 52-60 Salatiga 50711 Jawa Tengah \\ *)email : 652013044@student.uksw.edu \\ ${ }^{* *}$ email: hartati.sucipto@,staff.uksw.edu
}

\begin{abstract}
The objectives of the study are to obtain optimum yield of extraction red rice bran oil, to determine the physico-chemical characteristics, and componen coumpounds. Data was analyzed using Nir Parametric Statistics by Friedmann test. The result showed the optimum extraction results was obtained by the ratio of substrate : solvent of $1: 8$ and the oil yield was $12.31 \pm 0.325 \%$. The physico properties of red rice bran oil were greenish brown colour, with a density ranged from $0.908 \pm 0.014$ to $0.922 \pm 0.014(\mathrm{~g} / \mathrm{mL})$, and the water content ranged from $0.87 \pm 0.06$ to $0.91 \pm$ $0.02 \%$. The chemical properties of red rice bran oil were: the acid number ranged from $116.41 \pm$ 1.22 to $118.11 \pm 2.45(\mathrm{mg} \mathrm{NaOH} / \mathrm{g})$; the saponification number ranged from $193.74 \pm 21.88$ to $199.62 \pm 12.63(\mathrm{mg} \mathrm{KOH} / \mathrm{g})$; and the peroxide number ranged from $24.37 \pm 2.44$ to $26.07 \pm 4.88$ $(\mathrm{mgek} / \mathrm{kg})$, respectively. Oils was analyzed used GC-MS. The chemical components of rice bran oil are oleic acid (46.24\%), palmitic acid (18.25\%), linoleic acid (13.29\%), 9-octadecane (7.76\%).
\end{abstract}

Key Words: Red Rice Bran, Red Rice Bran Oil, Physico-Chemical Properties, GC-MS, Chemical Compounds.

\begin{abstract}
ABSTRAK
Tujuan penelitian untuk memperoleh rendemen optimal minyak bekatul beras merah, menentukan karakteristik fisiko kimiawi, dan komposisi kimiawinya. Data dianalisis menggunakan Statistik Nir Parametrik dengan uji Friedmann. Hasil penelitian menunjukkan hasil ekstraksi optimal diperoleh pada nisbah bahan : pelarut sebesar 1: 8 dengan hasil rendemen minyak sebesar $12,31 \pm 0,325 \%$. Sifat fisikawi hasil minyak bekatul beras merah adalah berwarna coklat kehijauan, dengan massa jenis berkisar $0,908 \pm 0,014-0,922 \pm 0,014(\mathrm{~g} / \mathrm{mL})$, dan kadar air berkisar $0,87 \pm$ $0,06-0,91 \pm 0,02 \%$. Sedangkan sifat kimiawi hasil minyak bekatul beras merah adalah sebagai berikut: bilangan asam berkisar 116,41 $\pm 1,22-118,11 \pm 2,45(\mathrm{mg} \mathrm{NaOH} / \mathrm{g})$; bilangan penyabunan berkisar 193,74 $\pm 21,88-199,62 \pm 12,63(\mathrm{mg} \mathrm{KOH} / \mathrm{g})$; dan bilangan peroksida berkisar 24,37 \pm $2,44-26,07 \pm 4,88$ (mgek/kg). Minyak dianalisis dengan menggunakan GC-MS. Komponen kimiawi penyusun minyak bekatul adalah asam oleat $(46,24 \%)$, asam palmitat $(18,25 \%)$, asam linoleat $(13,29 \%), 9$-oktadekenal $(7,76 \%)$.
\end{abstract}

Kata kunci: Bekatul Beras Merah, Minyak Bekatul Beras Merah, Sifat Fisiko-Kimiawi, GC-MS, Komponen Kimiawi.

\section{Pendahuluan}

Indonesia mempunyai produktivitas

padi yang cukup besar, dan setiap tahunnya meningkat. Menurut Badan Pusat Statistik produksi padi pada tahun 2015 sebesar 75,36 juta ton Gabah Kering

Extraction and Chemical Compounds Identification of Red Rice Bran Oil Using Gas Chromatography - Mass Spectrometry (GC-MS) Method 
Giling (GKG) yang artinya mengalami kenaikan sebesar 4,51 juta ton $(6,37$ persen) dibandingkan 2014 (BPS, 2016). Peningkatan produksi padi dapat membawa dampak yang baik bagi masyarakat Indonesia. Sementara bekatul (polish) merupakan lapisan sebelah dalam dari butiran padi, termasuk sebagian kecil endosperm berpati (Nasir dkk., 2009).

Semakin banyak jumlah produksi padi mengakibatkan bertambah besar juga hasil sisa penggilingan padi. Penggilingan padi menghasilkan produk samping seperti menir, beras pecah, sekam, dan bekatul (dedak padi). Menir dan beras pecah digiling menjadi tepung sebagai bahan berbagai kue dan makanan lainnya, sedangkan sekam dapat dimanfaatkan untuk bahan bakar serta kompos, bekatul saat ini hanya dimanfaatkan untuk pakan ternak dan belum banyak digunakan sebagai sumber pangan manusia (Hapsari dkk., 2013).

Bekatul padi memiliki kandungan minyak bervariasi antara 12-25\% tergantung dari tingkat penyosohan dan varietas padi. Kandungan asam lemak bebas dalam minyak bekatul juga tergantung dari kondisi serta lamanya penyimpanan bekatul. Bekatul bisa berubah menjadi tengik jika disimpan terlalu lama dan dalam keadaan lembab.
Enzim lipase yang terdapat dalam bekatul adalah penyebab ketengikan ini. Lipase akan menghidrolisis minyak (trigliserida) menjadi gliserol dan asam lemak bebas (Suprijana dkk., 2002).

Minyak bekatul atau rice bran oil merupakan minyak hasil ekstraksi bekatul padi. Minyak bekatul dapat dikonsumsi serta mengandung vitamin, antioksidan dan nutrisi yang diperlukan tubuh manusia. Minyak bekatul mengandung beberapa jenis lemak serta asam lemak. Minyak bekatul juga mengandung antioksidan alami tokoferol, tokotrienol dan orizanol yang berfungsi menangkal radikal bebas dalam tubuh terutama sel kanker, serta membantu menurunkan kolesterol dalam darah, kolesterol liver, dan menghambat menopause. Oleh karena itu, minyak bekatul dapat dimanfaatkan sebagai suplemen pangan untuk meningkatkan kualitas kesehatan manusia (Nasir dkk., 2009).

Data penelitian minyak bekatul yang dilaporkan umumnya menggunakan bekatul beras putih. Sedangkan data untuk minyak bekatul beras merah jarang dijumpai maka dari itu penelitian ini bertujuan melengkapi data minyak bekatul dengan menggunakan bekatul beras merah. 
Berdasarkan latar belakang di atas maka tujuan penelitian adalah sebagai berikut:

1. Memperoleh rendemen optimal minyak bekatul beras merah melalui metode sokletasi.

2. Menentukan sifat fisiko-kimiawi minyak bekatul yang diperoleh.

3. Identifikasi komponen kimiawi minyak bekatul beras merah dengan kromatografi gas-spektroskopi massa.

\section{Metode Penelitian}

Bahan yang digunakan dalam penelitian ini adalah bekatul beras merah yang diperoleh dari penggilingan padi di Mranggen, Kabupaten Demak, Jawa Tengah. Sedangkan bahan kimiawi yang digunakan adalah N-heksan, akuades, etanol, kloroform, asam asetat glacial, asam klorida, natrium tiosulfat, indikator fenolftalein, natrium hidroksida, kalium iodida, kalium hidroksida. Semua reagensia yang digunakan produk Merck, Jerman.

Piranti yang digunakan antara lain: neraca analitik dengan ketelitian 0,0001 g (Mettler H 80, Mettler Instrument Corp., USA), neraca analitik dengan ketelitian 0,01 g (Ohaus TAJ602, Ohaus Corp., USA), grinder, oven, buret, peralatan ekstraksi soxhlet, rotary evaporator
(Buchii R0114, Swiss), peralatan gelas, dan Gas Chromatography-Mass Spectrometry.

\section{Ekstraksi Minyak Bekatul (Nasir dkk., 2009 termodifikasi)}

Sampel beras merah disiapkan, kemudian sampel dihaluskan dengan grinder lalu diayak menggunakan screen ukuran 20 mesh. Sampel hasil ayakan, dimasukkan dalam oven dengan temperatur $110^{\circ} \mathrm{C}$ selama 15 menit, kemudian sampel ditimbang sebanyak 50 gram. Sampel diekstrak dengan pelarut nheksana dengan nisbah bahan : pelarut masing-masing $1: 5 ; 1: 6 ; 1: 8$ pada suhu 70 - $80{ }^{\circ} \mathrm{C}$ menggunakan piranti soxhlet selama 1,5 jam.

\section{Pemisahan Minyak dari Pelarut (Nasir dkk., 2009 termodifikasi)}

Hasil ekstraksi diuapkan dengan rotary evaporator sampai pekat kemudian dipindahkan ke labu yang lebih kecil dan diuapkan sampai diperoleh minyak bebas pelarut. Rendemen minyak dapat dihitung dengan rumus:

$$
\% \text { rendemen minyak kasar }=\frac{\text { massa minyak }}{\text { massa sampel }} \times 100 \%
$$

Extraction and Chemical Compounds Identification of Red Rice Bran Oil Using Gas

Chromatography - Mass Spectrometry (GC-MS) Method 
Karakterisasi Sifat Fisiko-Kimia Minyak

Penentuan warna dan aroma dilakukan secara deskriptif, sedangkan penentuan secara kuantitatif dilakukan untuk beberapa parameter yaitu untuk penentuan kadar air, rendemen, massa jenis, bilangan asam, bilangan penyabunan, dan bilangan peroksida sesuai SNI 01-3555-1998.

\section{Analisa Komposisi Kimiawi Minyak \\ Bekatul}

Analisis komposisi kimiawi minyak bekatul dilakukan dengan mnggunakan kromatografi gas spektroskopi massa Gas (Universitas Diponegoro, Semarang) sebelum diinjeksikan, sampel minyak diesterifikasi terlebih dahulu. Dengan suhu oven kolom $65^{\circ} \mathrm{C}$, suhu injeksi $250^{\circ} \mathrm{C}$ dan tekanan $74,5 \mathrm{kPa}$ dengan total aliran 602,4 $\mathrm{mL} / \mathrm{menit}$ dan kecepatan linier 40,0 cm/detik. Purge flow 3,0 $\mathrm{mL} /$ menit dengan split ratio 500,0.

\section{Analisa Data}

Data rendemen minyak bekatul beras merah dianalisis menggunakan Metoda Sidik Ragam Statistik Nir Parametrik dengan uji Friedmann. Sebagai perlakuan adalah nisbah bahan : pelarut yaitu $1: 5 ; 1: 6 ; 1: 8$ dengan 5 kali ulangan (Steel dan Torrie, 1995).

\section{Hasil dan Pembahasan}

Rendemen Minyak Bekatul Beras Merah Antar Berbagai Nisbah Pelarut

Rataan rendemen minyak bekatul beras merah antar nisbah pelarut dalam waktu ekstraksi 1,5 jam berkisar antara $9,43 \pm 1,144 \%$ sampai $12,31 \pm 0,325 \%$ (Tabel 1).

Tabel 1. Rataan Rendemen Minyak Bekatul Beras Merah $(\% \pm \mathrm{SE})$ antar Berbagai Nisbah Pelarut dalam Waktu Ekstraksi 1,5 jam.

\begin{tabular}{lccc}
\hline & \multicolumn{3}{c}{ Nisbah Pelarut } \\
\cline { 2 - 4 } & $1: 5$ & $1: 6$ & $1: 8$ \\
\hline Rataan \pm & $9,43 \pm$ & $10,33 \pm$ & $12,31 \pm$ \\
SE (\%) & 1,144 & 1,075 & 0,325 \\
\hline Ket: SE= Kesalahan Baku Taksiran. \\
Keterangan ini juga berlaku untuk Tabel \\
2.
\end{tabular}

Dari Tabel 1 menunjukkan bahwa semakin banyak jumlah pelarut yang digunakan maka semakin tinggi pula rendemen minyak bekatul merah yang dihasilkan. Menurut Lestari (2006) hal ini terkait dengan semakin besar volume 
pelarut maka daya kelarutannya akan semakin tinggi hingga mencapai titik optimum (Gambar 1).

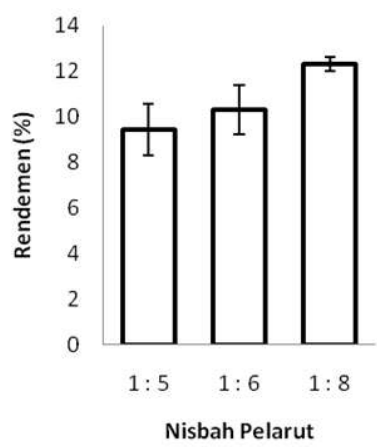

Gambar 1. Histogram Rataan Rendemen Minyak Bekatul Beras Merah

Lebih lanjut Suryandari (1981) menambahkan bahwa semakin banyak volume pelarut yang bertambah maka daya kelarutan juga bertambah sampai mencapai titik optimum yaitu kondisi pelarut menjadi jenuh.

\section{Sifat Fisiko-Kimiawi Minyak Bekatul \\ Beras Merah}

Sifat-sifat fisikawi (aroma, warna, kadar air, dan massa jenis) dan kimiawi (bilangan asam, penyabunan, dan peroksida) minyak bekatul beras merah disajikan dalam Tabel 2 berikut ini:

Tabel 2. Sifat Fisiko Kimiawi Minyak Bekatul Beras Merah Antar Berbagai Nisbah

\begin{tabular}{|c|c|c|c|c|c|}
\hline \multirow[b]{2}{*}{ Sifat Fisiko-Kimiawi } & \multicolumn{3}{|c|}{ Rataan \pm SE } & \multirow{2}{*}{$\begin{array}{c}{ }^{*} \text { Minyak } \\
\text { Bekatul } \\
\text { Standard } \\
\text { A.O.C.S }\end{array}$} & \multirow[b]{2}{*}{$* *$ Penelitian lain } \\
\hline & $1: 5$ & $1: 6$ & $1: 8$ & & \\
\hline Aroma & Khas bekatul & Khas bekatul & Khas bekatul & $(-)$ & Khas bekatul \\
\hline Kadar air (\%) & $0,91 \pm 0,02$ & $0,90 \pm 0,04$ & $0,87 \pm 0,06$ & $(-)$ & $(-)$ \\
\hline Massa Jenis ( $\mathrm{g} / \mathrm{mL})$ & $0,908 \pm 0,014$ & $0,915 \pm 0,017$ & $0,922 \pm 0,014$ & $0,920-0,928$ & 0,89 \\
\hline Wama & Coklat kehijauan & Coklat kehijauan & Coklat kehijauan & $(-)$ & Hijau kecoklatan \\
\hline Bilangan Asam (mg NaOH/g) & $116,41 \pm 1,22$ & $118,11 \pm 2,45$ & $117,26 \pm 3,24$ & $(-)$ & $(-)$ \\
\hline Bilangan Penyabunan (mg KOH/g) & $193,74 \pm 21,88$ & $199,62 \pm 12,63$ & $196,68 \pm 12,63$ & $183-194$ & 179,17 \\
\hline Bilangan Peroksida (mgrek/kg) & $24,93 \pm 2,44$ & $26,07 \pm 4,88$ & $24,37 \pm 2,44$ & $(-)$ & $(-)$ \\
\hline
\end{tabular}

Ket:*Kriteria minyak bekatul menurut A.O.C.S (American Oil Chemist Society)

** Mardiah dkk., 2006

( - ) Tidak ada data

\section{Aroma dan Warna Minyak Bekatul}

\section{Beras Merah}

Minyak bekatul beras merah yang dihasilkan berwarna coklat kehijauan dengan aroma khas bekatul. Untuk aroma memiliki aroma yang sama dengan penelitian yang dilakukan oleh Mardiah dkk (2006) sedangkan untuk warna memiliki perbedaan warna hal ini disebabkan karena warna yang lebih

Extraction and Chemical Compounds Identification of Red Rice Bran Oil Using Gas

Chromatography - Mass Spectrometry (GC-MS) Method 
dominan disebabkan karena pemanasan yang terlalu berlebihan. Minyak bekatul beras merah yang dihasilkan tidak memiliki perbedaan aroma dan warna antar nisbah bahan dan pelarut (Gambar 2).

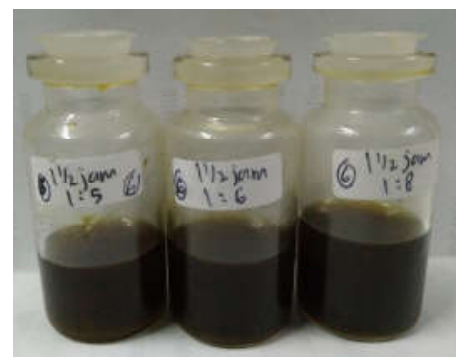

Gambar 2. Minyak Bekatul Beras Merah Kadar Air

Kadar air minyak bekatul beras merah yang diperoleh berkisar antara 0,87 $\pm \quad 0,06 \%$ sampai $0,91 \pm 0,02 \%$. Kandungan air dalam minyak merupakan salah satu parameter penentu kualitas minyak. Semakin tinggi kadar air dalam minyak maka kualitas minyak semakin rendah hal ini karena air merupakan salah satu katalisator reaksi hidrolisis minyak yang menghasilkan asam lemak bebas (Handajani dkk., 2010).

\section{Massa Jenis}

Rataan massa jenis minyak bekatul beras merah berkisar antara 0,908 $\pm 0,014$ $\mathrm{g} / \mathrm{mL}$ sampai $0,922 \pm 0,014 \mathrm{~g} / \mathrm{mL}$ (Tabel 2). Hasil ini tidak terlalu berbeda dari massa jenis minyak yang dilakukan oleh
Mardiah dkk (2006) yaitu 0,89 g/mL. Hasil ini menunjukkan bahwa nisbah 1:5 massa jenisnya paling sedikit dibandingkan 1:6 dan 1:8. Hal ini disebabkan karena semakin sedikitnya jumlah volume pelarut yang digunakan maka semakin lebih cepat jenuh pelarut tersebut untuk melakukan ekstraksi. Sehingga komponen-komponen yang terekstrak lebih dahulu dan yang terbanyak adalah komponen-komponen yang memiliki bobot molekul yang kecil (Lestari., 2006).

\section{Bilangan Asam}

Bilangan asam merupakan ukuran dari jumlah asam lemak bebas, yang dihitung berdasarkan berat molekul dari asam lemak maupun dari campuran asam lemak. Asam lemak bebas merupakan asam lemak yang terpisah dari triglesirida, digliserida, monogliserida dan gliserin bebas yang terbentuk karena adanya pemanasan, proses oksidasi, atau adanya kandungan air dalam minyak yang menyebabkan minyak mengalami proses hidrolisis. Semakin tinggi kandungan asam lemak bebas dalam minyak, maka menunjukkan bahwa semakin tinggi pula kerusakan yang dialami oleh minyak (Herwanda., 2011). Berdasarkan hasil 
penelitian diperoleh bilangan asam minyak bekatul beras merah yang bekisar antara $116,41 \pm 1,22 \mathrm{mg} \mathrm{NaOH} / \mathrm{g}$ sampai $118,11 \pm 2,45 \mathrm{mg} \mathrm{NaOH} / g$. Salah satu cara untuk menurunkan kandungan asam lemak bebas dalam minyak adalah melalui proses pemurnian.

\section{Bilangan Penyabunan}

Bilangan penyabunan yaitu jumlah alkali yang dibutuhkan untuk menyabunkan minyak. Rataan bilangan penyabunan yang diperoleh berdasarkan penelitian berkisar antara 193,74 $\pm 21,88$ $\mathrm{mg} \mathrm{KOH} / \mathrm{g}$ sampai $199,62 \pm 12,63 \mathrm{mg}$ $\mathrm{KOH} / \mathrm{g}$. Hal ini belum sesuai dengan Standard Minyak Bekatul menurut A.O.C.S dan hasilnya juga berbeda dengan penelitian yang dilakukan oleh Mardiah dkk (2006) yaitu yang hanya sebesar 179,17 mg KOH/g. Hal ini disebabkan karena tinggi rendahnya bilangan peyabunan dipengaruhi oleh asam lemak berantai pendek berarti memiliki berat molekul rendah maka akan memiliki bilangan penyabunan yang relatif tinggi dan sebaliknya minyak dengan berat molekul besar akan memiliki bilangan penyabunan yang relatif kecil. Yang berarti besar kecilnya bilangan penyabunan ditentukan oleh berat molekul asam lemak penyusunnya. Selain itu hal yang menyebabkan berbedanya bilangan penyabunan adalah dari faktor budidaya, yaitu tempat tumbuh, iklim, musim, waktu panen, faktor genetik lainnya serta proses ekstraksi minyak (Ketaren., 1986 dalam Handayani dkk., 2015).

\section{Bilangan Peroksida}

Rataan bilangan peroksida yang dihasilkan berdasarkan penelitian yang dilakukan yaitu berkisar antara 24,37 \pm $2,44 \mathrm{mgek} / \mathrm{kg}$ sampai $26,07 \pm 4,88$ mgek/kg. Bilangan peroksida adalah nilai terpenting untuk menentukan derajat kerusakan pada minyak. Asam lemak tidak jenuh bisa mengikat oksigen pada ikatan rangkapnya sehingga membentuk peroksida. Pembentukan senyawa peroksida biasanya merupakan awal proses oksidasi minyak. Naiknya nilai bilangan peroksida merupakan indikator dan peringatan bahwa minyak tidak lama lagi akan berbau tengik (Herwanda., 2011).

\section{Identifikasi Senyawa Penyusun Minyak \\ Bekatul Beras Merah}

Minyak yang dianalisis dengan GCMS adalah minyak hasil ekstraksi dengan perbandingan pelarut 1:8. Hasil analisa 
disajikan pada Gambar 3. Kromatogram diantaranya merupakan senyawa yang menunjukkan adanya 15 senyawa dalam dominan.

minyak bekatul beras merah dan 4

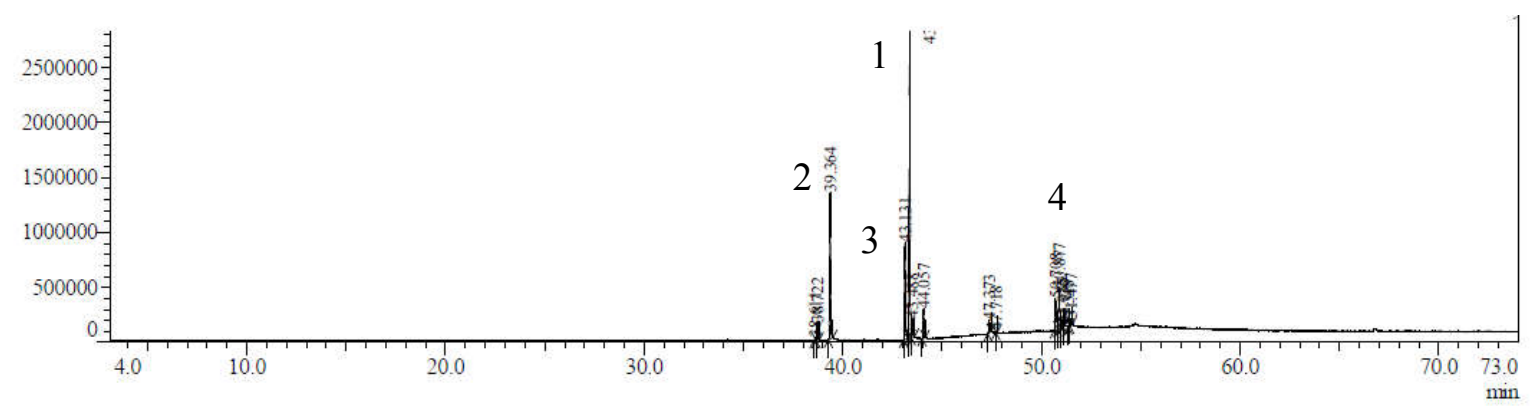

Gambar 3. Kromatogram GC-MS Minyak Bekatul Beras Merah

Identifikasi tiap puncak dalam dengan data base Wiley untuk kromatogram dilakukan dengan menentukan jenis senyawanya (Gambar mencocokkan spektrum MS tiap puncak 4).
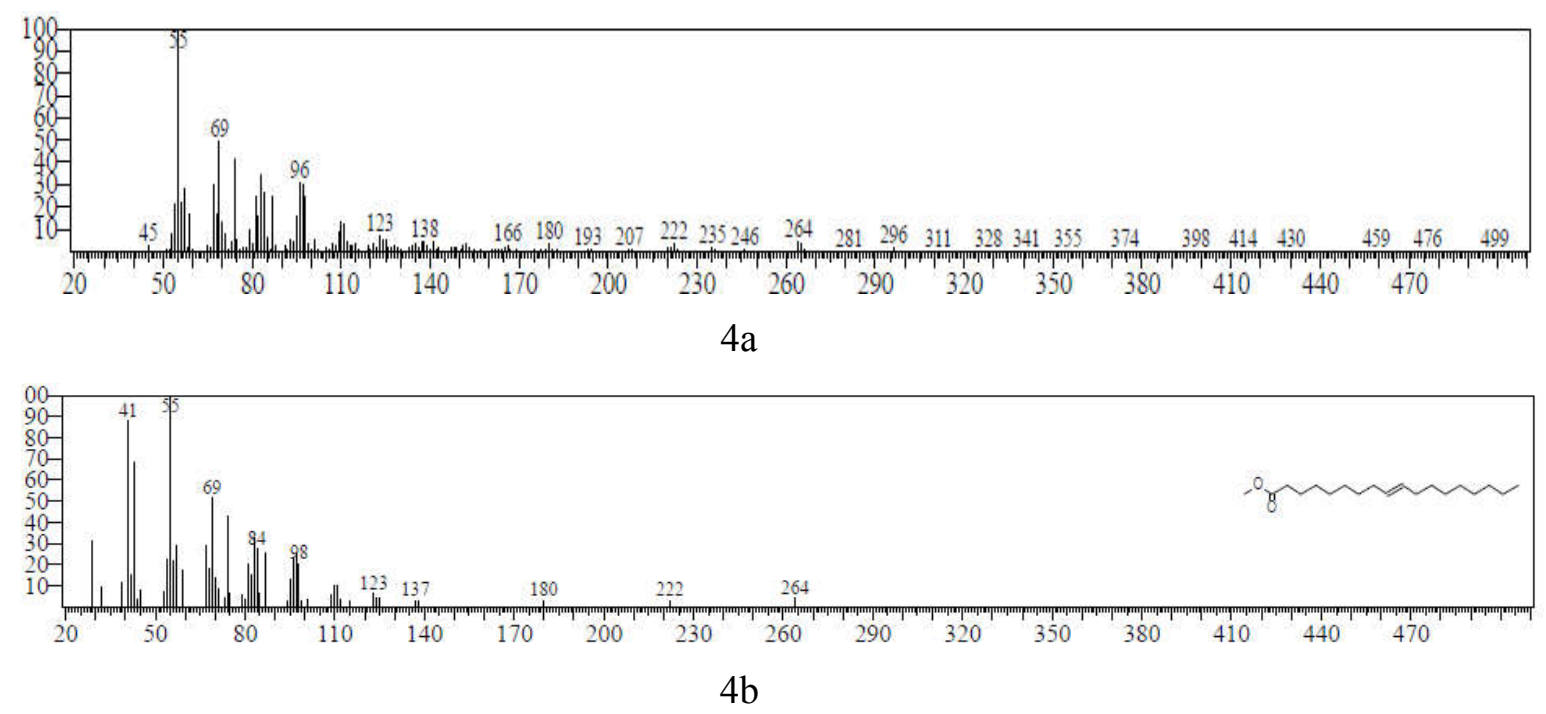

Gambar 4. (4a) Spektrum Puncak No 1 Minyak Bekatul Beras Merah(4b) Spektrum 9-Octadecenic acid, methyl ester sesuai Data Base Wiley

Gambar 4a merupakan spektrum merupakan spektrum referensi data base puncak no. 1 dari spektra minyak bekatul Wiley yaitu 9-Octadecenoic acid, methyl beras merah sedangkan Gambar $4 \mathrm{~b}$ ester yang memiliki BM pada m/z 264 .

Extraction and Chemical Compounds Identification of Red Rice Bran Oil Using Gas

Chromatography - Mass Spectrometry (GC-MS) Method 
Bila dilihat fragmentasinya, maka spektrum 4a merupakan puncak yang mengacu pada senyawa 9-Octadecenoic acid, methyl ester dan senyawa ini memiliki BM pada m/z 296 dengan rumus molekul $\mathrm{C}_{19} \mathrm{H}_{36} \mathrm{O}_{2}$. Selanjutnya terjadi pelepasan senyawa $\mathrm{CH}_{3} \mathrm{OH}$ yang ditunjukkan pada puncak $[\mathrm{M}-32]^{+}(\mathrm{m} / \mathrm{z}$ molekul senyawa 9-Octadecenoic acid, methyl ester pada spektrum referensi data base Wiley. Puncak-puncak yang muncul pada fragmentasi senyawa tersebut adalah $\mathrm{m} / \mathrm{z} 296,264,222,180,166,138,123,96$, 69, 55, dan 45. Kemungkinan pola fragmentasi yang muncul pada senyawa tersebut adalah sebagai berikut:

264) yang merupakan puncak massa ion

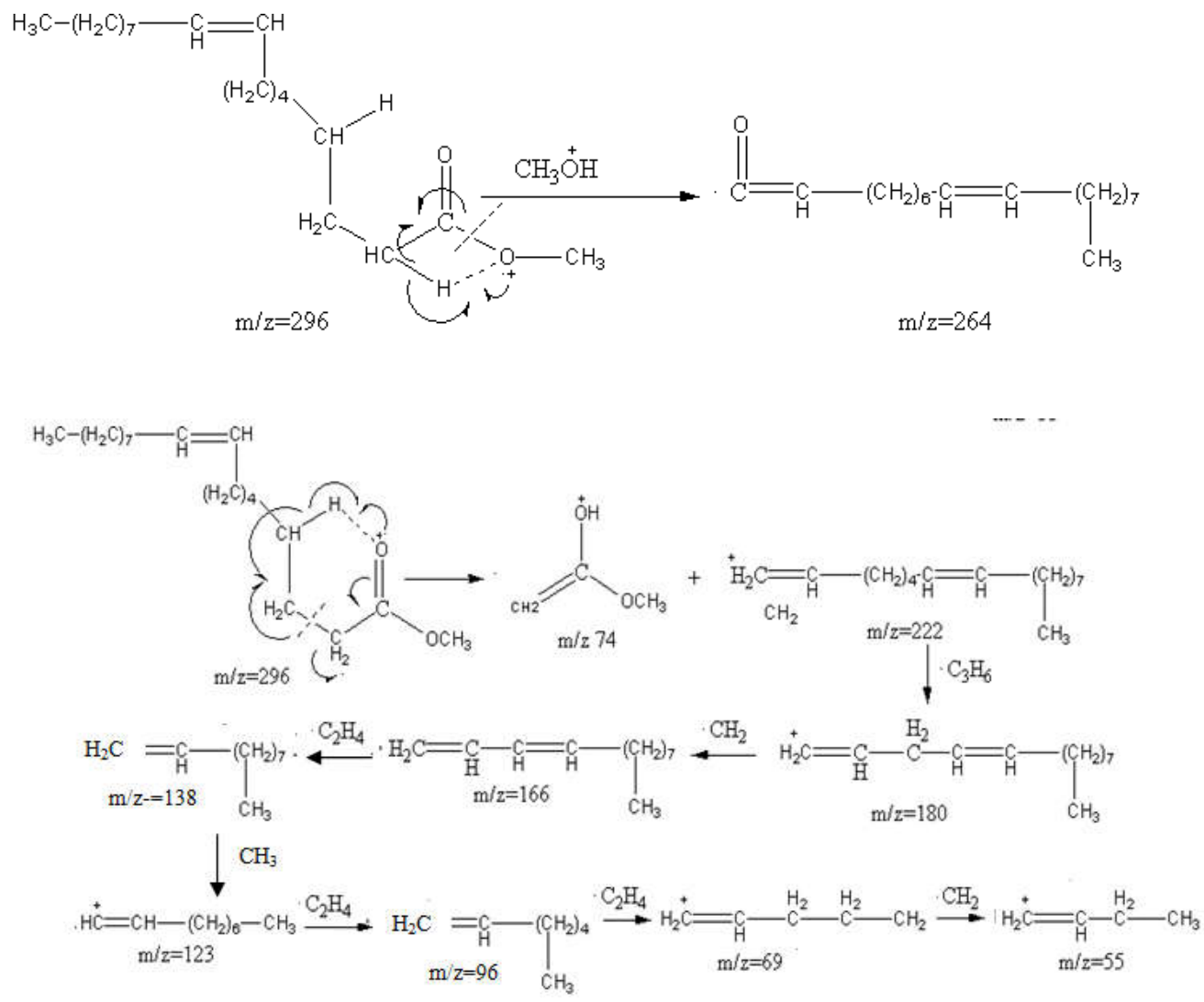

Gambar 5. Usulan Pola Fragmentasi 9-Octadecenoic acid, methyl ester

Sumber: Pradana dkk., 2014

Dengan cara yang sama puncak-

puncak yang lain juga dianalisa, kemudian

hasil identifikasi disajikan dalam Tabel 3.

Extraction and Chemical Compounds Identification of Red Rice Bran Oil Using Gas Chromatography-Mass Spectrometry (GC-MS) Method 
Tabel 3. Komposisi Kimiawi Penyusun Minyak Bekatul Beras Merah

\begin{tabular}{|c|c|c|c|c|c|}
\hline $\begin{array}{c}\text { No. } \\
\text { Puncak }\end{array}$ & $\begin{array}{l}\text { Waktu } \\
\text { Retensi }\end{array}$ & Komponen Kimia & $\mathrm{BM}$ & $\begin{array}{l}\text { Kandungan } \\
\text { Relatif (\%) }\end{array}$ & $\begin{array}{c}\text { Rumus } \\
\text { Molekul }\end{array}$ \\
\hline 1. & 43,369 & $\begin{array}{c}\text { 9-Octadecenoic acid, } \\
\text { methyl ester } \\
\text { (Metil Oleat) }\end{array}$ & 296 & 41,19 & $\mathrm{C}_{19} \mathrm{H}_{36} \mathrm{O}_{2}$ \\
\hline 2. & 39,364 & $\begin{array}{c}\text { Pentadecanoic acid, 14- } \\
\text { methyl-, methyl ester } \\
\text { (Metil Palmitat) }\end{array}$ & 270 & 18,25 & $\mathrm{C}_{17} \mathrm{H}_{34} \mathrm{O}_{2}$ \\
\hline 3. & 43,131 & $\begin{array}{l}\text { 9,12-Octadecadienoic } \\
\text { acid, methyl ester } \\
\text { (Metil Linoleat) }\end{array}$ & 294 & 13,29 & $\mathrm{C}_{19} \mathrm{H}_{34} \mathrm{O}_{2}$ \\
\hline 4. & 50,877 & 9-Octadecenal & 266 & 7,76 & $\mathrm{C}_{18} \mathrm{H}_{34} \mathrm{O}$ \\
\hline
\end{tabular}

Tabel 3 menunjukkan bahwa kadar 46,24\%; 18,25\%; 13,29\%; dan minyak bekatul beras merah tersusun oleh $\quad 7,76 \%$ secara berturut-turut.

4 komponen penyusun utama, secara berturut-turut dimulai dari yang paling dominan adalah asam oleat, asam palmitat, asam linoleat, dan 9-
Bila dibandingkan dengan penelitian Sumasa dkk (2011) dan Zuhra (2006) menggunakan bekatul beras putih hasil penelitian ini agak berbeda (Tabel 4). oktadekenal. Dengan masing-masing

Tabel 4. Perbandingan dengan Peneliti Lain

\begin{tabular}{cccccc}
\hline \multirow{2}{*}{ Bekatul Beras Merah } & \multicolumn{5}{c}{ Bekatul Beras Putih } \\
\cline { 3 - 6 } & & \multicolumn{2}{c}{ Sumasa dkk., 2011 } & \multicolumn{2}{c}{ Zuhra., 2006 } \\
\hline Kandungan & $\%$ & Kandungan & $\%$ & Kandungan & $\%$ \\
Kimiawi & & Kimiawi & & Kimiawi & $\%$ \\
\hline Asam oleat & 41,19 & + & 40,23 & + & 42,87 \\
Asam palmitat & 18,25 & + & 22,83 & + & 27,94 \\
Asam linoleat & 13,29 & + & 29,35 & + & 27,48 \\
9-oktadekenal & 7,76 & - & - & - & - \\
\hline
\end{tabular}

Extraction and Chemical Compounds Identification of Red Rice Bran Oil Using Gas Chromatography - Mass Spectrometry (GC-MS) Method 
Tabel 4 menunjukkan kandungan asam oleat minyak bekatul beras merah dan putih relatif sama yaitu sekitar $40 \%$, sedangkan asam palmitat minyak bekatul beras putih lebih tinggi daripada minyak bekatul beras merah, bahkan untuk asam linoleat minyak bekatul beras putih jauh lebih tinggi daripada minyak bekatul beras merah, lebih dari 2x lipat. Senyawa 9oktadekenal yang dikenal sebagai oleik aldehid sebesar 7,76\% ditemukan pada minyak bekatul beras merah. Senyawa ini biasanya ditemukan pada tanaman Humulus lupulus (familia Cannabinaceae). Humulus lupulus disebut "Common Hop / Hop" tanaman ini bertanggung jawab pada karakteristik aroma dan rasa pahit pada bir. Oleik aldehid juga ditemukan pada aroma daging yang dimasak, 9-oktadekenal termasuk dalam golongan Fatty Aldehydes. Senyawa ini memiliki rantai panjang aldehid dengan rantai setidaknya 12 atom karbon, biasanya digunakan sebagai penyedap rasa dalam makanan hewan (Pubchem, 2005).

\section{Kesimpulan}

Berdasarkan hasil penelitian maka dapat ditarik kesimpulan bahwa:

1. Rendemen minyak bekatul beras merah optimal diperoleh pada waktu ekstraksi selama 1,5 jam dengan nisbah bahan : pelarut sebesar $1: 8$ dan rendemen minyak sebesar $12,31 \pm 0,325 \%$.

2. Sifat fisikawi rendemen minyak bekatul beras merah yang dihasilkan adalah warna coklat kehijauan, dengan massa jenis berkisar 0,908 $\pm 0,014-$ $0,922 \pm 0,014(\mathrm{~g} / \mathrm{mL})$, dan kadar air berkisar 0,87 $\pm 0,06-0,91 \pm 0,02 \%$. Sedangkan sifat kimiawi minyak bekatul beras merah yang dihasilkan adalah bilangan asam berkisar 116,41 \pm $1,22-118,11 \pm 2,45(\mathrm{mg} \mathrm{NaOH} / \mathrm{g})$; bilangan penyabunan berkisar 193,74 \pm $21,88-199,62 \pm 12,63(\mathrm{mg} \mathrm{KOH} / \mathrm{g})$; dan bilangan peroksida berkisar 24,37 $\pm 2,44-26,07 \pm 4,88$ (mgek $/ \mathrm{kg})$.

3. Komponen kimiawi penyusun minyak bekatul beras merah adalah asam oleat (46,24\%), asam palmitat (18,25\%), asam linoleat (13,29\%), 9-oktadekenal $(7,76 \%)$.

\section{Daftar Pustaka}

Badan Standarisasi Nasional Indonesia, SNI 01-3555-1998: Cara Uji Lemak dan Minyak. Badan Standarisasi Nasional Indonesia, Jakarta.

BPS, 2016, Statistik Indonesia, BPS, Jakarta.

Extraction and Chemical Compounds Identification of Red Rice Bran Oil Using Gas Chromatography - Mass Spectrometry (GC-MS) Method 
Handajani, S., Manuhara, G.J., \& Anandito, R.B.K., 2010, Pengaruh Suhu Ekstraksi Terhadap Karakteristik Fisik, Kimia, dan Sensoris Minyak Wijen (Sesamum Indicum L.), Jurnal Agritech, 30(2), pp. 116-122.

Handayani, R., Rukminita, S., \& Gumilar, I., 2015, Karakteristik FisikoKimia Minyak Biji Bintaro (Cerbera manghas L) dan Potesinya sebagai Bahan Baku Pembuatan Biodisel, Fakultas Perikanan dan Ilmu Kelautan, Universitas Padjadjaran, Bandung.

Hapsari, R.P., Fikri, A.Y., Zullaikah, S., \& Rachimoellah, H.M., 2013, Isolasi dan Karakterisasi Oryzanol dari Minyak Dedak Padi, Jurnal Teknik Pomit, 1(1), pp. 1-7.

Herwanda, A.E., 2011, Kajian Proses Pemurnian Minyak Biji Bintaro (Cerbera manghas L) Sebagai Bahan Bakar Nabati, Skripsi, Fakultas Teknologi Pertanian, Institut Pertanian Bogor, Bogor.

Lestari, W.W., 2006, Pengaruh Nsbah Rimpang dengan Pelarut dan Lama

Pubchem, (2005), 9-Octadecenal. https://pubchem.ncbi.nlm.nih.gov/c ompound/9octadecenal\#section=Top, Diakses tanggal 26 April 2017.

Steel, R.G.D. \& Torrie, J.H., 1995, Prinsip dan Prosedur Statistika,
Ekstraksi Terhadap Mutu Oleoresin Jahe Merah (Zingiber officinale var. rubrum), Jurnal Akuatika, 6(2), pp. 177-186.

Mardiah., Widodo, A., Trisningwati, E., \& Purijatmiko, A., 2006, Pengaruh Asam Lemak dan Konsentrasi Katalis Asam terhadap Karakteristik dan Konversi Biodiesel pada Transesterifikasi Minyak Mentah Dedak Padi, Jurusan Teknik Kimia, Institut Teknologi Sepuluh Nopember (ITS), Surabaya.

Nasir, S., Fitriyanti, \& Kamila, H., 2009, Ekstraksi Dedak Padi Menjadi Minyak Mentah Dedak Padi (Crude Rice Bran Oil) dengan Pelarut N-Hexane dan Ethanol, Jurnal Teknik Kimia, 16(2), pp. 110.

Pradana, R. C., Soetjipto, H., \& Kristijanto, A.I., 2014, Karakterisasi dan Komposisi Kimia Minyak Biji Petai Cina (Leucaena Leucochepala (Lam.) de Wit), Skripsi, Universitas Kristen Satya Wacana, Salatiga.

Penerjemah Bambang Sumantri, Gramedia Pustaka, Jakarta.

Sumansa, T.T.L., Pabesak, R.V., \& Kristijanto, A.I., 2011, Bekatul sebagai Sumber Minyak Jantung dan Bioetanol (Solusi Inovatif untuk Mengatasi Kesehatan dan Energi Berbasis Kimia Hijau), Program Kreativitas Mahasiswa -

Extraction and Chemical Compounds Identification of Red Rice Bran Oil Using Gas Chromatography - Mass Spectrometry (GC-MS) Method 
DIKTI, Universitas Kristen Satya Wacana.

Suprijana, O., Hidayat, A.T., \& Soedjanaatmadja, U.M.S., 2002, Bekatul Padi sebagai Sumber Produksi Minyak dan Isolat Protein, Jurnal Bionatura, 4(2), pp. 61-68.
Suryandari, S., 1981, Pengambilan Oleoresin dengan Cara Solvent Extraction, BPIHP, Bogor.

Zuhra, C.F., 2006, Etanolisis Minyak Dedak Padi yang Diekstraksi secara Perendeman, Jurnal Sains Kimia, 10(1), pp. 1-3. 